\title{
Model of Developing the Availability of Engineers to Innovative Activity for High-Tech Industry
}

\author{
Angelina Olegovna Bagateeva ${ }^{1}$, Guliya Nailevna Akhmetzyanova ${ }^{2}$ \\ ${ }^{1}$ PhD, Associate Professor, Philology Department, Naberezhnye Chelny Institute (branch) of Kazan Federal University, \\ Scopus Id: http://www.scopus.com/authid/detail.url?authorId=56440163500; ORCID \\ ID: http://orcid.org/0000-0002-2884-0322 \\ ${ }^{2}$ PhD, Associated Professor, Department of Transport Systems Service, Naberezhnye Chelny Institute (branch) of Kazan Federal \\ University, Scopus Id: http://www.scopus.com/authid/detail.url?authorId=56580342400, \\ ORCID ID: http://orcid.org/0000-0003-0422-3108
}

\begin{abstract}
The article reveals the content of readiness for innovative activity as an integrative characteristic of the professional training of engineers for high-tech production. Various approaches to defining the concept of innovation are shown. According to various authors, the term "innovative activity" is considered as a type of activity, as a process, as a system of activities. The article presents the conceptual provisions used in the development of a model for the formation of engineers' readiness for innovation in high-tech production. Also shown is the author's interpretation of the structural components

Models of the readiness of engineers to innovate for the hightech industry. The relationship between all components of the model is determined. The result of the developed model of an engineer for a high-tech industry is a specialist who combines both engineering training and knowledge in the field of management; capable of developing new high-tech products; conduct business planning in the innovation area; spend management audit of functional divisions of the high-tech industry; to develop strategic, tactical and operational plans, budgets of high-tech enterprises; to increase the efficiency of functioning of enterprises in knowledge-intensive industries, etc. This model, being universal, can serve as the basis for the development of methods, technologies for training specialists in other areas and can be translated for the organization of similar educational systems.
\end{abstract}

Keywords: Engineer, availability, innovative activity, hightech industry.

\section{INTRODUCTION}

The main motive force of economic development, both in a single country and globally, is knowledge-based technology. Economic transformations in Russia have led to a change in the situation in the domestic industry. There is an urgent need for specialists who are able to comprehensively address the issues of production management and its organization in the changed conditions. Today, we need a new type of specialists with both theoretical knowledge and practical skills of an engineer and a manager. The role of high-tech industries is intensifying, the production of innovative products is being increased, the quality of designs of products and services is improved. In these conditions, there is a real need for the developing of a fundamentally new type of engineers capable, on the one hand, to understand in depth the object of high-tech business, be scientifically substantiate and capable to organize work at all stages of the life cycle of high-tech products. On the other hand, such an engineer should possess knowledge and skills of a manager, be able to cope with groups of people, establish business connections. Such a specialist should have theoretical knowledge and practical skills of both an engineer and a manager. Therefore, the problem of developing the availability of engineers to innovative activity for high-tech production becomes particularly relevant. System, complex approach to developing the availability of engineers for hightech production to innovative activity give the chance to graduates to be professionally mobile and demanded in the labor market of the high-tech industry enterprises.

\section{METHODS}

The following research methods were used: observation, direct analysis, elementary-theoretical analysis, modeling. Observation as a method of cognition has allowed to obtain primary information in the form of a set of empirical statements and establish primary schematization of the concept interpretation of "innovative activity". Direct analysis has shown that there is no unambiguous interpretation of the concept of "innovative activity" in the theory and practice of higher education.

Researchers define innovative activity in different ways:

- as a type of activity associated with the transformation of ideas into technologically new or improved products, services, introduced in the market, new or improved technological processes or production methods [1,2];

- as a process $[3,4]$;

- as a system of activities for the use of scientific, technical and intellectual potential in order to obtain a new or improved product or service, a new method of their production [5].

The use of elementary-theoretical analysis method and 
modeling method has allowed us to study and analyze the conceptual positions of building a model of a specialist (a model of a specialist, including vocational training, personal qualities, physical, mental, moral health and general cultural literacy [6]; invariant model of an employee of automobile profile in the form of an activity model and a personality model [7]; model of a specialist as a description of the mandatory requirements for the future specialist on the part of the employer [8]) and build our own model of an engineermanager ready for innovative activity for high-tech industry.

\section{RESULTS AND DISCUSSION}

In our research, we consider availability for innovation as an integrative characteristic of professional training of engineers for high-tech production, which includes the following components: the intellectual component necessary to ensure effective implementation of the life cycle of innovative products; the activity component, which implies a professional individual style of activity for solving innovative problems; creative component, which involves the consideration of professional activity not as a combination of ready-made forms and methods of work, but as the acquisition of certain experience, and then its change, transformation; innovation management, considered as a system of training and decision-making aimed at the developing, support and development of innovative and technical potential of the enterprise; motivational component that characterizes a meaningful attitude to professional activity, awareness of its importance, the presence of a persistent cognitive interest in innovations and their use in the professional sphere; communicative component that provides communication support for innovation.

When developing the model of developing of engineers' availability for innovation in high-tech production, we were guided by the basics of pedagogical modeling [9], as well as the following conceptual provisions: expansion of objects and areas of professional activity; advanced reflection of the development of high-tech production; foreseeing socioeconomic changes in society; ensuring the strategic development of the potential of the future engineer; forecasting the main trends in the development of fundamental and applied science, high-tech production.

The model developed by us for the developing of engineers' availability for innovation in high-tech production includes target, theoretical and methodological, structural and content, instrumental and technological, and performance-diagnostic blocks [10].

The target block is determined by a social order that defines the goals and objectives of training engineers for high-tech production. The main goal of training engineers is to develop the availability of engineers for innovation. We define tasks based on the structure of engineers' availability for innovation: developing of a system of engineering knowledge, skills and abilities that contribute to successful professional activity; training in the field of Economics, organization and management; developing of a set of personal characteristics and professional qualities of an engineer [11,12].

The theoretical and methodological block includes the requirements of professional standards, Federal state educational standards, methodological approaches (system, acting as a theoretical and methodological strategy for the developing of engineers' availability for innovation; competence-based, which allows determining the set of professional competencies formed in the process of preparing engineers for innovation; personal-activity, which determines the need for individualization of training and assumes subjectsubject interaction between teachers and students; functional, defining the specifics of an activity from the point of view of its versatility and allowing to form the basis of the structure of the management component in the process of training an engineer-a for high-tech production; problem-based design, aimed at the developing and acquisition of professional knowledge in the field of high-tech production, practical knowledge and design skills in the process of mastering professional competence, which ensures the highest efficiency of engineering and management work) and the main principles of developing engineers' availability for innovation: the principle of partnership, which involves various forms of cooperation between higher educational institutions and industry enterprises; the principle of conscientiousness, which allows you to consciously manage creative processes; the principle of integration of education, which contributes to the development of creative thinking on the basis of combining different areas of science; the principle of variability, which involves different ways of implementing innovation; the principle of subjectivity, which ensures the implementation of creative activity of subjects of innovation [13].

Structural unit is a phased training of engineers to innovation and include: structural and logical scheme of training disciplines and their interrelation; we have developed structural components of availability for innovative activities that are part of professional competence in the FES (Federal Educational Standard); developed training and methodological support of the model [14].

The tool and technology block specifies the used pedagogical technologies of training, forms and means of preparing engineers for innovation. Since the pedagogical system of engineer training - and the concept is based on the fundament of professional education, interdisciplinary integration of management and technical knowledge in the process of training, professional education, identification technology of this teaching process involves the use of a variety of traditional technologies, combining them with modern interactive technologies, complexity, the penetration of one technology to another, which should contribute to developing the ability of students to generate ideas and solve problems [15]. Thus, one of the indicators of an engineer's availability for innovation is his ability to solve search and inventive tasks. One of the constructive and productive methods of developing this ability can be TRIZ-pedagogy [16].

A special place in solving the problem of developing of professional competence of engineers is occupied by the method of visualization of training as a means of developing 
the production and technological type of professional activity. Among the visualization methods, we can use stochastic simulation, intelligence maps, process modeling, etc. [17].

The performance-diagnostic block that characterizes the effectiveness of the model developed by us is considered as a set of diagnostic tools used for monitoring and evaluating the engineer's availability for innovation. We have defined the diagnostic methods used (observation, questionnaire, testing, interviewing, analysis of completed works, self-assessment), evaluation criteria (ability and availability for innovation, quality of developed projects, developing of social and personal qualities), as well as the levels of developing of an engineer's availability for innovation (low, medium, high) [18].

It should be noted that the performance-diagnostic block has a feedback with the target, theoretical and methodological, structural and content, and tool-technological blocks, which allows not only to monitor the process of developing of engineers' availability for innovation in high-tech production at various stages, but also, based on the results obtained, to correct it in a timely manner.

\section{SUMMARY}

The availability of innovation as an integrative characteristic of professional training of engineers for high-tech production was studied. Various approaches to defining the concept of innovation were given. According to various authors, the term "innovation activity" is considered as a type of activity, as a process, as a system of activities. The article presents the conceptual provisions used in the development of a model for the formation of engineers' availability for innovation in hightech production. The author's interpretation of the structural components of the model of engineers' availability for innovation for the high-tech industry is also shown. The relationship between all the model components is defined. The result of the developed model of an engineer for the high-tech industry is a specialist who combines both engineering training and knowledge in the field of management; is able to develop new high-tech products; conduct business planning in the innovation sphere; conduct a management audit of functional divisions of the high-tech industry; develop strategic, tactical and operational plans, budgets of high-tech enterprises; improve the efficiency of enterprises in high-tech industries, etc. This model, being universal, can serve as the basis for the development of methods and technologies for training specialists in other areas and can be translated for the organization of similar educational systems.

\section{CONCLUSIONS}

One of the modern pedagogical technologies used in preparing engineers for innovation is the technology of advanced training, according to which the entire educational process is aimed at activating, developing the student's mental activity, and self-development.

The most effective means of developing an engineer's availability for innovation in the system of higher professional education is the project training technology, the result of which is the ability of an engineer to create an innovative product, or significantly modify or qualitatively change a previously existing object.

The model developed by us allows us to imagine the process of developing of engineers' availability for innovation in the conditions of modern higher education. Its implementation will ensure a high level of training of engineers for high-tech production. This model, being universal, can serve as the basis for the development of methods and technologies for training specialists in other areas and can be translated for the organization of similar educational systems.

\section{ACKNOWLEDGEMENTS}

The work is performed according to the Russian Government Program of Competitive Growth of Kazan Federal University.

\section{REFERENCES}

[1] V.E. Andreev, Innovatsionnyiy menedzhment [Innovation management]: textbook, Yaroslavl State university named after P.G. Demidov, 160 p., 2011.

[2] Official website of information on innovations. URL: http://www.vesti.ru/doc.html?id=341389.

[3] V.V. Manuylenko, Suschnost innovatsiy, innovatsionnogo protsessa $\mathrm{v}$ retrospektive $\mathrm{i} \mathrm{V}$ sovremennyih usloviyah [The Essence of Innovation, Innovation Process in Retrospect and in Modern Conditions], Finances and Credit, No. 41 (521), pp. 21 31, 2012.

[4] I. Polushkina, I. Malyavina, Suschnost innovatsiy i problemyi perehoda $\mathrm{k}$ innovatsionnoy ekonomike $\mathrm{v}$ Rossii [The essence of innovations and problems of transition to innovation economy in Russia], Bulletin of Nizhny Novgorod University. n.a. N.I. Lobachevsky, No. 2, 2012.

[5] N.V. Sergeev, Ekonomika predpriyatiy [Economy of enterprise]: textbook. 2nd ed., Finance and statistics, 310 p., 2005.

[6] O.Yu Hatsrinova, Podgotovka konkurentosposobnyih spetsialistov-inzhenerov $\mathrm{v}$ usloviyah laboratornyih praktikumov po tehnologii kompozitsionnyih materialov [Training of competitive engineers in the conditions of laboratory practicum on technology of composite materials], Bulletin of Kazan technological University, No. 12, pp. 358-363, 2010.

[7] G.N. Akhmetzyanova, Kompetentnostnyiy podhod k sisteme nepreryivnogo professionalnogo obrazovaniya pri podgotovke rabotnikov dlya avtomobilnoy otrasli [Competence approach to the system of continuing professional education in the training of employees for the automotive industry], Bulletin of Kazan technological University, No. 4, pp. 349-355, 2009. 
[8] B. I. Seleznev, Model organizatsii podgotovki spetsialistov $\mathrm{v}$ oblasti vyisokih tehnologiy [Model of organization of training in the field of high technologies], University management: practice and analysis, №5-6, pp. 89-94, 2003.

[9] I.V. Dmitrieva, Struktura innovatsionnoy deyatelnosti v sostave inzhenernoy podgotovki bakalavra [Structure of innovative activity as a part of engineering training of the bachelor], Modern problems of science and education, No. 1, pp. 262-264, 2013.

[10] N.S. Ponomareva, Formirovanie gotovnosti buduschih inzhenerov $\mathrm{k}$ innovatsionnoy deyatelnosti $\mathrm{v}$ obrazovatelnom protsesse vuza [Forming the availability of future engineers to innovation in the educational process of the university]: thesis ... of the candidate of pedagogical sciences, Bryansk, 190 p., 2011.

[11] V. Manuylov, Modeli formirovaniya gotovnosti k innovatsionnoy deyatelnosti [Models of formation of availability to innovative activity], Higher education in Russia, No. 7, pp. 56-64, 2004.

[12] L.I. Gure, A.A. Kirsanov, V.V. Kondratev, I.E. Yarmakeev, Integrativnyie osnovyi innovatsionnogo obrazovatelnogo protsessa $\mathrm{v}$ vyisshey professionalnoy shkole [Integrative framework of innovative educational process in higher professional schools]: monograph, Moscow, VINITI, 288 p., 2006.

[13] A.O. Bagateeva, G.N.Akhmetzyanova, Modular Technology Of Foreign Language Training Of Technical University Students, Modern Journal of Language Teaching Methods (MJLTM), Vol. 7, Issue. 9.2, September 018-022, pp. 157-160, 2017.

[14] N.Sh. Valeeva, A.O. Bagateeva, G.N. Akhmetzyanova, "K probleme formirovaniya inoyazyichnoy kommunikativnoy kompetentnosti bakalavrov $\mathrm{V}$ tehnicheskom vuze" [To the problem of formation of foreign language communication competence of bachelors in a technical college], Bulletin of Kazan technological University, No. 11, Vol. 17, pp. 251-253, 2014.

[15] Z. Pronina, G.N. Akhmetzyanova, A.O. Bagateeva, "Project Approach as a Means of Forming the Availability of Bachelors to Innovate Activity in Information Technologies", Tarih Kultur Ve Sanat Arastirmalari Dergisi-Journal of History Culture and Art. Research, Volume: 7 Issue: 4, pp. 428-434, 2018.

[16] G.N. Akhmetzyanova, A.O. Bagateeva, "Psychoeducational Support of Foreign Language Training in Higher School", Modern Journal of Language Teaching Methods, Volume: 7 Issue: 12, pp. 178-182, 2017.

[17] G.N. Akhmetzyanova, A.O. Bagateeva, "Computer Linguodidactics in Foreign Language Training of Technical University Students", A Journal of Multidisciplinary Science and Technology (IIOAB),
Vol. 10, Issue: Multidisciplinary Social Science \& Management, pp. 134-137, 2019.

[18] G.N. Akhmetzyanova, A.O. Bagateeva, "Educational Environment of the College as a Factor of Professional Competence Forming of Future Middle Level It Specialists", Journal of Advanced Research in Dynamical and Control Systems, Vol.11, Is.8 Special Issue, pp.1834-1836, 2019.

Angelina O. Bagateeva is an Associate Professor of Philology Department at Naberezhnye Chelny Institute of Kazan Federal University. In 2005 she graduated from the Kama State Polytechnic Institute with a degree in Economics and Computer Sciences and a year later became a graduate of Nizhniy Novgorod Linguistic University. She received her $\mathrm{PhD}$ from Kazan National Research Technological University in Theory and Methods of Professional Education. Her research interests include methods of professional education, foreign languages training, ICT in education.

Guliya N. Akhmetzyanova is an Associated Professor of Naberezhnye Chelny Institute of Kazan Federal University. She graduated from the Kazan State University n.a. V.I. Lenin, Faculty of computational mathematics and cybernetics. Prior to joining Naberezhnye Chelny Institute of Kazan Federal University, Guliya N. worked as a programmer in KamAZ. She received her Ph.D. from Kazan National Research Technological University in Theory and Methods of Professional Education. She is supervising the work of postgraduates and graduate students. Her research interests include theory and methods of professional education, information technology in education, science and management. 